\title{
POD PORTION AND TYPE EFFECTS ON SEX, GROWTH AND YIELD IN FLUTED PUMPKIN
}

\author{
P. E. OGBONNA \\ Department of Crop Science, University of Nigeria Nsukka, 410001, Nigeria
}

(Received 9 March, 2009, accepted 28 July, 2009)

\begin{abstract}
Fluted pumpkin (Telfaria occidentalis Hook) is a native of West Africa and a perennial vine but cultivated as annual crops under the traditional farming system of West Africa. A study was conducted at the experimental farm of the Department of Crop Science, University of Nigeria, Nsukka to determine the effect pod portion and pod type of fluted pumpkin on sex ratio, growth and yield in the crop. Seeds obtained from three portions (head, middle and tail) of three pod types (1, 2, and 3) were planted out in a 3 x 3 factorial in randomised complete block design with 3 blocks. The relative percentages of male and female plants plot $^{-1}$ obtained from seeds from the head, middle and tail portions were 31.5 and 68.5, 28.5 and 71.5, and 31.7 and 68.3, respectively. For the pod types 1 , 2 and 3, the relative percentages of male and female plants plot ${ }^{-1}$ were 27.2 and 72.8, 25.1 and 74.1, and 39.3 and 60.7, respectively. The highest percentage of female plants was obtained from seeds from middle portion of pod type 2. Mean number of sprouts seeds ${ }^{-1}$ was 1.2 in head portion and 1.1 in both the middle and tail portions; while it was 1.0, for pod type 1 , and 1.2 for pod type 2 and 3 . Number of pods ha' ${ }^{-1}$ and weight of pod ha- were 15,922 and 39,000 $\mathrm{kg} \mathrm{ha}^{-1}, 13,699$ and 43,000 $\mathrm{kg} \mathrm{ha}^{-1}$; and 12,588 and 45,000 kg ha-1 for the head, middle and tail pod portions, respectively. For pod types, values of 13699 and $38000 \mathrm{~kg} \mathrm{ha}^{-1}, 16289$ and $43000 \mathrm{~kg} \mathrm{ha}^{-1}$, and 12,222 and $46000 \mathrm{~kg} \mathrm{ha}^{-1}$ were recorded from type 1,2 and 3, respectively. Positive correlation exited between percentages of female plants plot $^{-1}$ and vine length plant ${ }^{-1}$, leaves plant ${ }^{-1}$, pods ha-1 and weight of pod ha-1 Negative correlation occured with sprouts seed ${ }^{-1}$, branches plant ${ }^{-1}$ and pod weight. Number of sprouts seed ${ }^{-1}$ also had a positive association with branches plant ${ }^{-1}$, leaves plant ${ }^{-1}$, percentage of male plants, weight of pods ha ${ }^{-1}$, and pod weight.
\end{abstract}

Key Words: Pod yield, sexual dimorphism, sprouts seed ${ }^{-1}$, Telfairia occidentalis

\section{RÉSUMÉ}

Une étude avait été menée dans le champ expérimental du Département de Science de Plantes, Université du Nigéria, Nsukka afin de déterminer l'effet de portion de gousse ainsi que du type de gousse du potiron cannelé (Telfairia occidentalis Hook) sur le sexe ratio, la croissance et le rendement de la culture. Les graines obtenues de trois parties (supérieure, terminale et centale) de trois types de gousses (1, 2 et 3 ) avaient été plantées en $3 \times 3$ factoriel dans un modèle de block complétement aléatoires constitués de 3 blocks. Les pourcentages obtenu relatifs de plants mâles et femelles par parcelles de graines de la partie superieur, du milieu et les parties terminales étaient respectivement de 31,5 et 68,$5 ; 28,5$ et 71,5 ainsi que 31,7 et $68, .3$. Pour les types de gousse 1 , 2 et 3 , les pourcentages relatifs de plants mâles et femelles étaient respectivement de 27,2 et 72,8; 25,1 et 74,1 ainsi que de 39.3 et 60,7 . Le pourcentage plus élevé de plants femelles a été obtenu de graines de la partie centrale de la gousse de type 2. Nombre moyen de graines germées était de 1.2 pour la partie supérieure et de 1.1 aussi bien dans la partie du milieux que terminale, alors qu'il était 1.0 pour la gousse de type 1 et 1.2 pour gousse de type 2 et 3 . Le nombre de gousses par hectare et le poids de gousse par hectare étaient respectivement 15922 et $39000 \mathrm{~kg}$ par ha, 13699 et $43000 \mathrm{~kg}$ par ha et 12588 et $45000 \mathrm{~kg}$ par ha pour les portions supérieures, du milieu et terminales de gousse. Pour les types de gousse, les valeurs de 13699 et $38000 \mathrm{~kg}$ par ha, 16289 et $43000 \mathrm{~kg}$ par ha ainsi que 12,222 et $46000 \mathrm{~kg} \mathrm{ha}^{-1}$ avaient été enregistrées respectivement de type 1, 2 et 3. Une corrélation positive avait 
été également constatée entre les pourcentages de plantes femelle par parcelle et la longueur de croissance rampante de la tige par plante, le nombre de feuilles par plante, le nombre de gousses par ha, ainsi que le nombre de gousses par ha et une corrélation négative avec le nombre de germinations par semence, le nombre de branches par plant et de poids moyen de gousse. Le nombre de germinations par semences a également eu association positive avec le nombre de branches par plant, le nombre de feuilles par plant, pourcentage des plants males, le poids de gousses par ha et le poids moyen de gousse.

Mots Clés: Rendement en gousse, dimorphisme sexuel, germination par semences, Telfairia occidentalis

\section{INTRODUCTION}

Fluted pumpkin (Telfaria occidentalis Hook) is a member of the cucurbitaceae plant family. It is a native of West Africa and a perennial vine but cultivated as annual crops under the traditional farming system of West Africa. Fluted pumpkin is grown primarily for leaf which is popular for use in preparing assorted diet in many West African countries (Gill,1988). The seeds can also be eaten whole, ground or fermented into "Ogiri" which serve as condiments for making soap and sauce. Asiegbu (1987) reported that the seeds contain about 30.1 and $47 \%$ of protein and oil, respectively. He also noted that the essential amino acid content compare favourably with those of other legumes such as groundnut and soyabean.

Fluted pumpkin is dioecious, having separate male (staminate) plant and female (pistilate ) plant. The male plant bears only male flowers, while the female plant bears only female flowers and consequently bears the pod that contains the seeds. This is known as sexual polymorphism. In fluted pumpkin production, preference is on large succulent leaves. The female plants are known to produce large succulent leaves that attracts high premium prices in the markets. The male plants, on the other hand, produce small and less attractive leaves.

Because of the high productivity of the female plants, farmers prefer female to male. However, it has not been possible to separate seed into male and female seeds that will germinate into male or female plants. In fact, it is difficult to differentiate male plants from female plants before flower initiation in the crop. This has posed a serious problem and limitation to fluted pumpkin production. In their contribution, Ndukwe et al. (2005) reported that seeds that germinate to female plants are larger in size than those that germinate male plants. There is also speculation among indigenous farmers that seeds extracted from the head and tail portions of the fluted pumpkin pod develop into male plants, while those extracted from the middle portion develop into female plants.

This study was, therefore, carried out to determine the influence of pod portion and pod type on sex ration in fluted pumpkin; and identifying the effect of pod section and type on growth and yield attributes in the crop.

\section{MATERIALS AND METHODS}

The experiment was conducted at the Department of Crop Science Teaching and Research farm, University of Nigeria, Nsukka. It is located at latitude $06^{\circ} 52 \mathrm{~N}$, longitude $07^{\circ} 24^{\prime} \mathrm{E}$ and 447 meters above sea level. The material consisted of three pod types of fluted pumpkin obtained from the Department of Crop Science collections. The treatments comprised of three fluted pumpkin pod types (1, 2 and 3) (Table 1) and three pod portions (head, middle and tail). This resulted in nine treatment combinations, laid out in a factorial in randomised complete block design in three replications.

Two matured pods from each pod type were divided into three portions; head, middle and tail. Seeds contained in these portions were carefully

TABLE 1. Pod description of the 3 pod types of fluted pumpkin used in Nigeria

\begin{tabular}{lll}
\hline Pod types & \multicolumn{2}{c}{ Pod description } \\
\cline { 2 - 3 } & Size & Shape \\
\hline 1 & Large & Oblong \\
2 & Medium & Spherical \\
3 & Small & Round \\
\hline
\end{tabular}


extracted, and placed separately and labeled accordingly. The fluted pumpkin seeds were sown directly in the plots two days after extraction from the pods. Plant spacing was $1 \mathrm{~m} \mathrm{x} 1 \mathrm{~m}$ and sowing was at one seed per hole.

Data collected include days to $50 \%$ seedling emergence, number of sprouts seed ${ }^{-1}$, vine length plant $^{-1}$ at flower initiation, number of branches plant $^{-1}$ at flower initiation, and number of leaves plant $^{-1}$ at flower initiation. Others included male plants plot ${ }^{-1}$, female plants plot ${ }^{-1}$, number of pods $\mathrm{ha}^{-1}$, weight of pod ha' ${ }^{-1}$ and pod weight.

Data collected were subjected to analysis of variance according to the procedure outlined by Steel and Torrie (1980) for factorial experiments. Detection of differences between treatment means was carried out using the Fishers' LSD at 5\% probability level.

\section{RESULT}

Pod portion had significant effect only on number of leaves plant ${ }^{-1}$, number of pods ha- ${ }^{-1}$, weight of pods $h^{-1}$ and average pod weight (Table 2). Seeds from the head portion showed highest performances on number of sprouts seed ${ }^{-1}$ and

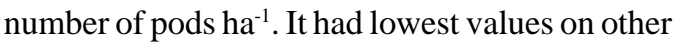
attributes, with the exception of male plants plot $^{-1}$ where it was higher than what was recorded from the middle portion. Seeds obtained from the middle pod portion recorded the highest vine length plant ${ }^{-1}$ and female plants plot ${ }^{-1}$. It, however, ranked second in leaves plant ${ }^{-1}$, pods ha $^{-1}$, weight of pods ha-1 and pod weight. Seed from the tail portion produced highest number of leaves plant $^{-1}$, male plants plant ${ }^{-1}$, weight of pod ha ${ }^{-1}$ and pod weight. It had the least value only on number of pods ha-1.

Among the plant attributes measured, only leaves plant ${ }^{-1}$, percentages of male plants and female plants, pods ha-1, weight of pods ha-1 and pod weight were significantly affected by pod types (Table 3). Pod type 1 recorded the highest vine length plant ${ }^{-1}$ and number of leaves plant ${ }^{-1}$. It ranked second in performance in other attributes with, the exception of number of sprouts seed ${ }^{-1}$, number branches plant ${ }^{-1}$ and weight of pods ha-1 where it had lowest values. Pod type 2 was highest in branches plant ${ }^{-1}$, female plants plot $^{-1}$ and pods ha ${ }^{-1}$. It recorded the least number of leaves plant ${ }^{-1}$, male plants plot $^{-1}$ and pod weight. Highest values of male plants plot $^{-1}$, weight of pods ha ${ }^{-1}$ and pod weight were recorded from Pod type 3 . It had lowest values only in vine length plant ${ }^{-1}$, female plants and pods $\mathrm{ha}^{-1}$. Though pod portion by pod type interaction showed non-significant effect $(\mathrm{P}>0.05)$ on all the attributes measured, there were noticeable differences between the treatment combinations (Table 4). Seed obtained from the head portion of pod types 3 produced the highest number of sprouts plant ${ }^{-1}$, while the least was obtained from seeds from head and also tail portions of Pod type 1 . The highest vine length plant ${ }^{-1}$ and leaves plant $^{-1}$ were obtained from seeds from middle portion of Pod type 2 and tail portion of Pod

TABLE 2. Effect of pod portion on the measured plant attributes in fluted pumpkin in Nigeria

\begin{tabular}{llllllllllll}
\hline Pod & \multicolumn{10}{c}{ Plant attributes } \\
\cline { 2 - 10 } Portion & DSE & NSS & $\begin{array}{c}\text { VLF } \\
(\mathrm{cm})\end{array}$ & NBF & NLF & POM & POF & NPH & $\begin{array}{r}\text { WPH } \\
(\mathrm{kg})\end{array}$ & $\begin{array}{c}\text { PW } \\
(\mathrm{kg})\end{array}$ \\
\hline Head & 14 & 1.2 & 25.9 & 3 & 12.4 & 31.5 & 68.5 & 15922 & 39000 & 2.45 \\
Middle & 14 & 1.1 & 29.5 & 3.3 & 14.7 & 28.5 & 71.5 & 13699 & 43000 & 3.14 \\
Tail & 14 & 1.1 & 27.3 & 3.3 & 15.9 & 31.7 & 68.3 & 12588 & 45000 & 3.58 \\
LSD (0.05) & NS & NS & NS & NS & 2.6 & NS & NS & 720 & 3500 & 0.62 \\
\hline
\end{tabular}

DSE $=$ Days to $50 \%$ seedling emergence, NSS $=$ Number of sprouts seed ${ }^{-1}, \mathrm{VLF}=$ Vine length plant ${ }^{-1}$ at flower initiation, NBF $=$ Number of branches plant ${ }^{-1}$ at flower initiation. NLF $=$ Number of leaves plant ${ }^{-1}$ at flower initiation, $\mathrm{POM}=$ percentage of male plants plot ${ }^{-1}, \mathrm{POF}=$ percentage of female plants plot ${ }^{-1}, \mathrm{NPH}=$ Number of pods ha- ${ }^{-1}, \mathrm{WPH}=$ Weight of pods ha ${ }^{-1}, \mathrm{PW}=$ Pod weight, $\mathrm{NS}=$ Non significant 
TABLE 3. Effect of pod types on the measured plant attributes in fluted pumpkin in Nigeria

\begin{tabular}{|c|c|c|c|c|c|c|c|c|c|c|}
\hline \multirow[t]{2}{*}{ Pod types } & \multicolumn{8}{|c|}{ Plant attributes } & \multirow[b]{2}{*}{$\begin{array}{c}\text { WPH } \\
(\mathrm{kg})\end{array}$} & \multirow[b]{2}{*}{$\begin{array}{l}\text { PW } \\
(\mathrm{kg})\end{array}$} \\
\hline & DSE & NSS & $\begin{array}{l}\text { VLF } \\
(\mathrm{cm})\end{array}$ & NBF & NLF & $\begin{array}{l}\text { POM } \\
(\%)\end{array}$ & $\begin{array}{c}\text { POF } \\
(\%)\end{array}$ & $\mathrm{NPH}$ & & \\
\hline 1 & 14 & 1.0 & 28.0 & 3.0 & 14.9 & 27.2 & 72.8 & 13699 & 38000 & 2.77 \\
\hline 2 & 14 & 1.2 & 27.9 & 3.5 & 11.3 & 25.1 & 74.9 & 16288 & 43000 & 2.64 \\
\hline 3 & 14 & 1.2 & 26.8 & 3.1 & 13.6 & 39.3 & 60.7 & 12222 & 46000 & 3.76 \\
\hline $\operatorname{LSD}(0.05)$ & NS & NS & NS & NS & 2.6 & 5.4 & 3.4 & 720 & 3500 & 0.62 \\
\hline
\end{tabular}

TABLE 4. Effect of pod portion by pod type interaction $(P \times T)$ on the measured plant attributes in fluted pumpkin in Nigeria

\begin{tabular}{|c|c|c|c|c|c|c|c|c|c|c|}
\hline \multirow{2}{*}{$\begin{array}{l}\mathrm{P} \times \mathrm{T} \\
\text { interaction }\end{array}$} & \multicolumn{10}{|c|}{ Plant attributes } \\
\hline & DSE & NSS & $\begin{array}{l}\text { VLF } \\
(\mathrm{cm})\end{array}$ & NBF & NLF & $\begin{array}{l}\text { POM } \\
(\%)\end{array}$ & $\begin{array}{l}\text { POF } \\
(\%)\end{array}$ & $\mathrm{NPH}$ & $\begin{array}{l}\text { WPH } \\
(\mathrm{kg})\end{array}$ & $\begin{array}{l}\text { PW } \\
(\mathrm{kg})\end{array}$ \\
\hline $\mathrm{H} 1$ & 14 & 1 & 28.4 & 3 & 14 & 30 & 70 & 17777 & 38000 & 2.14 \\
\hline M1 & 14 & 1 & 28.5 & 3 & 15 & 26 & 74 & 12222 & 48000 & 3.93 \\
\hline $\mathrm{T} 1$ & 14 & 2 & 27.2 & 3 & 17 & 26 & 74 & 111111 & 39000 & 3.51 \\
\hline $\mathrm{H} 2$ & 14 & 2 & 25.6 & 4 & 8 & 33 & 67 & 16666 & 40000 & 2.4 \\
\hline M2 & 14 & 2 & 31.1 & 3 & 10 & 20 & 80 & 16666 & 35000 & 2.1 \\
\hline $\mathrm{T} 2$ & 14 & 2 & 26.8 & 4 & 17 & 22 & 78 & 15555 & 53000 & 3.41 \\
\hline $\mathrm{H} 3$ & 14 & 3 & 23.8 & 3 & 16 & 31 & 69 & 13333 & 49000 & 3.68 \\
\hline M3 & 14 & 2 & 28.8 & 4 & 11.2 & 39 & 61 & 12222 & 45000 & 3.68 \\
\hline $\mathrm{T} 3$ & 14 & 2 & 27.8 & 3 & 14 & 47 & 53 & 111111 & 42000 & 3.78 \\
\hline $\operatorname{LSD}(0.05)$ & NS & NS & NS & NS & NS & NS & NS & NS & NS & NS \\
\hline
\end{tabular}

DSE $=$ Days to $50 \%$ seedling emergence, NSS $=$ Number of sprouts seed ${ }^{-1}, \mathrm{VLF}=$ Vine length plant ${ }^{-1}$ at flower initiation, NBF $=$ Number of branches plant ${ }^{-1}$ at flower initiation. NLF $=$ Number of leaves plant ${ }^{-1}$ at flower initiation, $\mathrm{POM}=$ percentage of male plants plot ${ }^{-1}, \mathrm{POF}=$ percentage of female plants plot $^{-1}, \mathrm{NPH}=$ Number of pods $\mathrm{ha}^{-1}, \mathrm{WPH}=$ Weight of pods ha ${ }^{-1}, \mathrm{PW}=$ Pod weight, NS $=$ Non significant

type 2, respectively. Among the nine treatment combinations, the highest male plants plot $^{-1}$ and female plants plot $^{-1}$ were recorded from seeds from tail portion of Pod type 3 and middle portion of Pod type 2, respectively. The highest number of pods ha-1 and weight of pods ha-1 were obtained from seeds from head portion of Pod type 1 and tail portion of Pod type 2, respectively. Seeds from middle portion of Pod type 1 gave the highest pod weight.

Correlation analysis for the plant attributes revealed significant negative $(\mathrm{P}<0.05)$ correlations between percentage of male plants, and female plants and between number of pods ha $^{-1}$ and pod weight (Table 5). It was also observed that percentage male plants had positive but non-significant $(\mathrm{P}>0.05)$ correlation with sprouts seed ${ }^{-1}$, branches plant ${ }^{-1}$ and pod weight. It had negative correlation with other attributes, with the exception of days to 50\% seedling emergence. Percentage female plants, on the other hand, showed positive but nonsignificant correlation with vine length plant ${ }^{-1}$, leaves plant ${ }^{-1}$, pods plant ${ }^{-1}$ and weight of pods $\mathrm{ha}^{-1}$. Number of pods ha-1, also had a positive association with vine length plant and branches plant $^{-1}$. Number of branches plant ${ }^{-1}$ correlated positively only with number of sprouts seeds ${ }^{-1}$, 
TABLE 5. Correlation matrix among the measured plant attributes in fluted pumpkin

\begin{tabular}{|c|c|c|c|c|c|c|c|c|c|c|}
\hline & DSE & NSS & $\begin{array}{l}\text { VLF } \\
\text { (cm) }\end{array}$ & NBF & NLF & $\begin{array}{c}\text { POM } \\
(\%)\end{array}$ & $\begin{array}{l}\text { POF } \\
(\%)\end{array}$ & $\mathrm{NPH}$ & $\begin{array}{l}\text { WPH } \\
(\mathrm{kg})\end{array}$ & $\begin{array}{l}\text { PW } \\
(\mathrm{kg})\end{array}$ \\
\hline DSE & - & - & - & - & - & - & - & - & - & - \\
\hline NSS & & - & -.556 & .139 & .038 & .134 & -.134 & -.207 & .219 & .214 \\
\hline VLF & - & & - & -.177 & -.299 & -.185 & .185 & .120 & -.494 & -.299 \\
\hline NBF & & & & - & -.356 & .079 & -.079 & .213 & .352 & -.079 \\
\hline NLF & & & & & & -.183 & .183 & -.429 & .532 & .536 \\
\hline POM & & & & & & - & $-1.000^{\text {t* }}$ & -.445 & -.017 & .394 \\
\hline POF & & & & & & & - & .445 & .017 & -.394 \\
\hline $\mathrm{NPH}$ & & & & & & & & - & -.283 & $-.919^{* *}$ \\
\hline WPH (kg) & & & & & & & & & - & .619 \\
\hline PW (kg) & & & & & & & & & & - \\
\hline
\end{tabular}

Note ${ }^{* *}=$ Correlation is significant at $1 \%$ level of probability. DSE $=$ Days to $50 \%$ seedling emergence, NSS $=$ Number of sprouts seed $^{-1}, \mathrm{VLF}=$ Vine length plant ${ }^{1}$ at flower initiation, NBF $=$ Number of branches plant ${ }^{1}$ at flower initiation. NLF $=$ Number of leaves plant ${ }^{-1}$ at flower initiation, $\mathrm{POM}=$ percentage of male plants plot $^{-1}, \mathrm{POF}=$ percentage of female plants plot $^{-1}, \mathrm{NPH}=$ Number of pods $\mathrm{ha}^{-1}, \mathrm{WPH}=$ Weight of pods ha- ${ }^{-1}, \mathrm{PW}=$ Pod weight

percentage female plants, weight of pods ha-1 and pod weight.

\section{DISCUSSION}

Seeding emergence occurred at 14 days after sowing, and pod portion and type had no influence on emergence. Schipper (2000) had reported that seed germination in Telfairia seeds occurs between 10-14 days after sowing. It will also be noted that seeds used in the study were well matured irrespective of the portion of the pod they were obtained.

The study showed that seeds from head portion produced more sprouts seed ${ }^{-1}$ than the other portions, while Pod type 2 and 3 had higher number of sprouts seed ${ }^{-1}$ than type1. Generally, number of sprouts ranged from one to three per seed.

Multiple seedlings from one seed do occur in Telfairia, a phenomenon known as polyembryony (Esiaba, 1982). It is a natural occurrence in the crop whereby a seed germinated 2-5 sprouts or seedlings (Odiyi, 2003). In the present study, number of sprouts ranged from one to three per seed. Seeds from head portion produced more sprouts seed ${ }^{-1}$ than the other portions, while Pod type 2 and 3 had more sprouts than type 1 . The occurrence of multiple seedlings will serve to overcome the problem of shortage of planting materials in Telfairia production. It was however observed that high number of sprouts seed ${ }^{-1}$ is associated with low vine length and number of branches plant ${ }^{-1}$. This may be attributed to higher competition between seedlings, which reduced growth and development. This also appeared to be responsible for low number of leaves plant ${ }^{-1}$ produced by seeds that germinated higher number of sprouts.

The observed more female plants compared the male plants was not in conformity with what was reported by Anyim and Akoroda (1983) that equal proportions of male and female plants is produced. Though the difference in the sex ratios between the pod portions was not statistically significant, the middle portion produced higher proportion of female plants than male plants. This tends to agree with the speculation by the local farmers who believed that middle portion produces higher female plants. It was, however, contrary to the findings of Agwu and Obiefuna (1987) that the tail portion produced more female plants than the head and middle portions.

Pod type 2 may be regarded as a type with higher female plants potential than the other two types, while type 3 will be noted for higher male plant production. However, since the choice is on higher female plant production, type 2 will be the preferred type. Moreover, low male proportion is never a problem to pod production 
since it has been reported that one male plant will produce enough pollen to pollinate 10 female plants (Schipper, 2000). The head portion, which produced high number of pods $\mathrm{ha}^{-1}$ was found to have low weight of pods ha-1. The reason may be that the pods produced by the head portion were small in size. This was confirmed by the low pod weight obtained from head portion. Large pods are more likely to contain more seeds than small size pods with many immature seeds. The seeds are the major, if not the only propagating material. The seeds are useful as food and also for industrial purposes. Seeds from the tail pod portion and Pod type 3 may be selected for large pod production.

The positive correlation between percentage female plant and vine length plant ${ }^{-1}$ and number of leaves plant ${ }^{-1}$ at flower initiation may be seen as an indication that these attributes could be used to identify the sexes at early growth stages. It also appears to confirm reports that female plants yield more, vegetative, than male plants. On the other hand, increased proportion of male plant has been shown to be positively associated with increase in number of sprouts seed ${ }^{-1}$. High number of sprouts seed ${ }^{-1}$ may therefore serve as a marker for identifying sexes at the seedling stage.

\section{REFERENCES}

Agwu, B.O.E. and Obiefuna, J.C. 1981. The effect of within pod seed position on the sex expression of fluted pumpkin Telfairia occidentalis. Procedings of the $10^{\text {th }}$ Annual
Conference off Horticulture Society of Nigeria. (HORTSON) held at Owerri, 8-13, November, 1987. pp. 37-39.

Anyim, O.A. and Akoroda, M.O. 1983. Determination of optimal sex ratio for maximum fruit yield in Telfairia occidentalis. Annual Report for NIHORT Ibadan, Nigeria. pp. 116-119.

Asiegbu, J.E. 1987. Some biochemical evaluation of fluted pumpkin seed. J.Sci. Food Agric. 40:151-155.

Esiaba, R.O. 1982. Cultivating fluted pumpkin in Nigeria. World crops. March/April. pp. 7072.

Gill, L.S. 1988. Taxonomy of Flowering Plants. African FEP Publisher Ltd. Ibadan, Nigeria. 109p.

Odiyi, A.C. 2003. Developmental patterns of the multiple seedling trait in Telfairia occidentalis Hook.. J. Sustain. Agric. Environ. 5:317-325.

Ndukwe, B. C., Obute, G.C. and Wang- Toby, I.L. 2005 Tracking sexual dimorphism in Telfariria occidentalis Hook F. (Cucurbitacceae) with morphological and molecular markers. African J. Biotech. 4:1245-1249.

Schipper, R.R. 2000. African indigenous Vegetables. An Overview of the Cultivated Species. Chatham UK: NRI/ACP-EU. Technical center for Agricultural and Rural Cooperation. V11+214P

Steel, R.G.D. and Torrie, J.H. 1980. Principles and Procedures of Statistics. $2^{\text {nd }}$ Ed. McGraw-Hill Book Co. N.Y. 350pp. 